\title{
Correction to: On the link between Chinese currency and its inpayments from and outpayments to trading partners: an asymmetric analysis
}

\author{
Mohsen Bahmani-Oskooee ${ }^{1} \cdot$ Jia Xu² \\ Published online: 1 November 2021 \\ (c) Springer Science+Business Media, LLC, part of Springer Nature 2021
}

\section{Correction to: Economic Change and Restructuring https://doi.org/10.1007/s10644-020-09317-1}

In the original publication, the corresponding author was wrong. The correct corresponding author is Dr. Jia Xu. This has been updated in the original publication.

Publisher's Note Springer Nature remains neutral with regard to jurisdictional claims in published maps and institutional affiliations.

The original article can be found online at https://doi.org/10.1007/s10644-020-09317-1.

\section{Jia Xu}

xujia@shisu.edu.cn

Mohsen Bahmani-Oskooee

bahmani@uwm.edu

1 The Center for Research On International Economics, Department of Economics, The University of Wisconsin-Milwaukee, Milwaukee, WI 53201, USA

2 School of Economics and Finance, Shanghai International Studies University, Shanghai 200083, China 